\title{
Age estimation by analysis of dental mineralization and its forensic contribution
}

\author{
Estimativa da idade por meio da análise da mineralização dentária e a sua contribuição forense \\ Estimación de la edad mediante el análisis de la mineralización dental y su contribución forense
}

Received: 08/16/2021 | Reviewed: 08/25/2021 | Accept: 09/09/2021 | Published: 09/11/2021

\author{
Barbara Kuhnen \\ ORCID: https://orcid.org/0000-0003-2586-4772 \\ São Paulo State University, Brazil \\ E-mail: kuhnenbarbara@gmail.com \\ Clemente Maia da Silva Fernandes \\ ORCID: https://orcid.org/0000-0002-5401-6265 \\ São Paulo State University, Brazil \\ E-mail: c.face@terra.com.br \\ Franciéllen de Barros \\ ORCID: https://orcid.org/0000-0001-5460-4334 \\ São Paulo State University, Brazil \\ E-mail: fran.dbrs@gmail.com \\ Julia Moreira Andrade \\ ORCID: https://orcid.org/0000-0002-9650-5390 \\ São Paulo State University, Brazil \\ E-mail: juliamoreiraandrade.27@gmail.com \\ José Scarso Filho \\ ORCID: https://orcid.org/0000-0002-8633-1120 \\ São Paulo State University, Brazil \\ E-mail: jose.scarso@icloud.com \\ Marcelo Gonçalves \\ ORCID: https://orcid.org/0000-0002-4548-7751 \\ São Paulo State University, Brazil \\ E-mail: marcelo.goncalves1970@unesp.br \\ Mônica da Costa Serra \\ ORCID: https://orcid.org/0000-0001-8820-2982 \\ São Paulo State University, Brazil \\ E-mail: monica.serra@unesp.br
}

\begin{abstract}
Age is an important factor in the formation of the uniqueness of individuals. The procedure for assessing age in situations that cannot determine chronological age, especially in court cases, is mandatory. The literature presents different methods to estimate the age of individuals because civil and criminal majority at 18 years is a milestone in Brazil and other countries. Thus, age estimation through the analysis of dental mineralization stages is important, as it is rarely affected by exogenous or endogenous factors. This study evaluates different methods used to estimate age through dental mineralization and its forensic contribution. The following databases were used: PubMed, Medline, Scopus, Web of Science, and Google Scholar, using the descriptors "age estimation", "dental age estimation", and "forensic dentistry", both isolated and combined. It was verified the reliability of the analysis of dental mineralization stages for age estimation. Some of the methods used for this purpose have not been tested in Brazilian individuals. There are no upto-date data on mineralization stages of permanent teeth for this population. Thus, current and specific data from the Brazilian population are required because the results to be obtained from new studies could benefit society, assisting the clarification of Justice in real-life situations.
\end{abstract}

Keywords: Forensic sciences; Human identification; Forensic dentistry; Forensic anthropology; Age determination by teeth.

\section{Resumo}

A idade é um importante fator na formação da singularidade do indivíduo. O procedimento de avaliação da idade em situações em que a idade cronológica não pode ser determinada, principalmente em casos judiciais, é obrigatório. A literatura apresenta diferentes métodos para estimar a idade dos indivíduos, pois maioridade civil e penal, aos 18 anos, é um marco no Brasil e em outros países. Assim, a estimativa da idade, por meio da análise dos estágios de mineralização dentária, é importante, pois raramente é afetada por fatores exógenos ou endógenos. Este estudo avalia diferentes métodos utilizados para a estimativa da idade por meio da mineralização dentária e a sua contribuição forense. Foram utilizadas como bases de dados: PubMed, Medline, Scopus, Web of Science e Google Scholar, utilizando os descritores "age estimation", "dental age estimation" e "forensic dentistry", de forma isolada e combinada. Verificou-se a confiabilidade de análise de estágios de mineralização dentária para a estimativa da idade; alguns dos métodos utilizados 
para esta finalidade não foram testados em indivíduos brasileiros. Não há dados atualizados referentes a estágios de mineralização de dentes permanentes para esta população. Assim, são necessários dados atuais e específicos provenientes da população nacional, pois os resultados a serem obtidos a partir do de novos estudos poderão beneficiar a sociedade, auxiliando, em situações reais, o esclarecimento da Justiça.

Palavras-chave: Ciências forenses; Identificação humana; Odontologia legal; Antropologia forense; Determinação da idade pelos dentes.

\section{Resumen}

La edad es un factor importante en la configuración de la singularidad del individuo. El procedimiento de evaluación de la edad en situaciones en las que no se puede determinar la edad cronológica, especialmente en los casos judiciales, es obligatorio. La literatura presenta diferentes métodos para estimar la edad de las personas, ya que la edad civil y penal de 18 años es un hito en Brasil y en otros países. Por tanto, la estimación de la edad, mediante el análisis de las etapas de mineralización dentaria, es importante, ya que rara vez se ve afectada por factores exógenos o endógenos. Este estudio evalúa diferentes métodos utilizados para estimar la edad a través del análisis dental y su aporte forense. Se utilizaron las siguientes bases de datos: PubMed, Medline, Scopus, Web of Science y Google Scholar, utilizando los descriptores "estimación de edad", "estimación de edad dental” y "odontología forense”, de forma aislada y combinada. Se verificó la confiabilidad del análisis de las etapas de mineralización dentaria para la estimación de la edad; algunos de los métodos utilizados para este propósito no han sido probados en personas brasileñas. No hay datos actualizados sobre las etapas de mineralización de los dientes permanentes para esta población. Por lo tanto, se necesitan datos actuales y específicos de la población nacional, ya que los resultados que se obtengan de nuevos estudios pueden beneficiar a la sociedad, ayudando, en situaciones reales, al esclarecimiento de la justicia.

Palabras clave: Ciencias forenses; Identificación humana; Odontología forense; Antropología forense; Determinación de la edad por los dientes.

\section{Introduction}

Age is an important factor in the formation of the uniqueness of individuals. Estimating the age of unidentified corpses for human identification is a traditional activity implemented by experts (Schmeling et al., 2007). The number of refugees is increasing worldwide, many of whom do not have identification documents. According to article 22 of the Convention on the Rights of Children of the United Nations (UN), enacted in Brazil in 1990 (Brasil, 1990 a), children under the age of 18 usually cannot be shipped back to their home countries.

The age estimation procedure in situations that cannot determine chronological age, especially in legal cases, is mandatory (Mohd Yusof et al., 2017). The most reliable and accurate way to correlate the development and growth of an individual is through the degree of dental development (Koshy \& Tandon, 1998; Kanchan-Talreja et al., 2012; Figueira Júnior \& Moura, 2014). Thus, assessing dental age with the analysis of radiographs and the mineralization stage of permanent teeth becomes viable, as it suffers less interference from factors that affect eruption (Carvalho et al., 1990; Babshet et al., 201 1; Kim et al., 2000; Kvaal, 2006; Yassin et al., 2020).

Some of the methods used to estimate age through dental mineralization have not been tested in Brazilian individuals (Guo et al., 2018). Thus, current studies performed with the Brazilian population are required, as it is not recommended to use data from a foreign population and apply them to another one.

This study evaluates different methods used to estimate age through dental mineralization and its forensic contribution.

\section{Methodology}

For developing this study, a narrative literature review with a qualitative approach was performed (Pereira et al., 2018), including experimental and non-experimental research from the theoretical and empirical literature. Searches were performed in the PubMed, Medline, Scopus, Web of Science, and Google Scholar databases using the descriptors of "age estimation", "dental age estimation", and "forensic dentistry". The search was performed separately and combined. The study included available full 
texts and that contained relevant data and characteristics on the study of age estimation through dental analysis, in either English or Portuguese. These texts were analyzed, concluding with a synthesis of knowledge. Articles that did not address the topic studied and written in languages other than Portuguese or English were excluded.

\section{Results and Discussion}

\section{Age estimation and its forensic importance}

Age is an important factor in shaping the uniqueness of individuals. Estimating the age of unidentified corpses and skeletons for human identification is a traditional activity implemented by experts, anthropologists, and archaeologists (Schmeling et al., 2007).

Currently, there are several situations in which age estimation is required in both living and dead individuals, and the number of refugees who often do not have identification documents is growing worldwide. Many of them ask for political asylum. According to article 22 of the Convention on the Rights of Children of the United Nations (UN), enacted in Brazil in 1990 (Brasil, 1990 a), children under the age of 18 usually cannot be shipped back to their home countries.

To either be criminally liable or not may have serious legal consequences. In Brazil, for example, criminal liability starts at 18 years of age, as determined by articles 228 of the Federal Constitution (Brasil, 1988), 27 of the Brazilian Penal Code (Brasil, 1940), and 104 of the Child and Adolescent Statute (Brasil, 1990 b). Thus, age assessment in situations that cannot determine chronological age is a mandatory procedure (Mohd Yusof et al., 2017). The scientific literature presents different methods to estimate age, especially in young people, and dental analysis stands out in this context (Kanchan-Talreja et al., 2012; Yassin et al., 2020).

Furthermore, age estimation is also essential for identifying cadavers, especially if ante-mortem data are not available (Melo et al., 2020).

\section{Age estimation through dental analysis}

One of the mechanisms in Forensic Dentistry is the use of teeth to estimate age, as dental hard tissues are the elements with higher ability to resist post-mortem changes caused by several factors, such as humidity, temperature increase, microbial activities, as well as the specificity and morphological characteristics unique to each individual (Meinl et al., 2008; Miranda et al., 2015).

The degree of dental development is the most reliable and accurate way to correlate the development and growth of an individual, and it can be considered an indicator of chronological age. Furthermore, unlike what is evident in the skeletal system, it is a system that presents low variation levels (Kanchan-Talreja et al., 2012).

Individuals have biological and chronological ages, which allows establishing the identity of a profile. Biological age corresponds to the state of health, that is, the condition of organs, tissues, and cells of an individual, while chronological age refers to the number of years counted from birth. Thus, biological age is used when chronological age is unknown (Garamendi et al., 2005). The third molar is an important element for Forensic Sciences because it is the last tooth formed in the eruption chronology and the only one that is completely formed after puberty. This means that the information this tooth provides can be used to estimate the criminal age of the individual investigated (Engström et al., 1983; Harris, 2007).

The study by Harris (2007), based on the method of Moorrees, evaluated the mineralization stages of lower third molars of 4,010 North American subjects, white and black, of both genders, aged between 3 and 25 years. The study found that crown formation occurred earlier in men. Black individuals showed earlier development of lower third molars than white individuals.

Different methods for estimating the age of an individual use dental radiological images to assess specific characteristics. Some particularly seek to estimate whether the individual under analysis is 18 years old. Some examples are the 
methods of Demirjian, who used as reference the dental development stages of seven permanent mandibular teeth on the left side using panoramic radiographs. Then, Demirjian \& Goldstein, in 1976, modified the method and started to use groups of four permanent lower teeth on the left side (Demirjian et al., 1973; Demirjian \& Goldstein, 1976); the Cameriere method was based on the physiological and continuous deposition of secondary dentin, which assesses the measurement reductions of the pulp chamber (Cameriere et al., 2004; Cameriere et al., 2007); the Moorrees method was based on the analysis of mineralization stages of permanent teeth (Moorrees et al., 1963); and the methods of Mincer (Mincer et al., 1993) and Olze (Olze et al., 2010) were based on the analysis of third molar mineralization. There are several methods described in the literature for estimating dental age, based on different criteria. However, age estimation using dental mineralization is the most reliable (Yassin et al., 2020).

\section{Age estimation through dental mineralization}

The tooth is the most durable element in the human body and is made up of cementum, enamel, dentin, and pulp. It can be clinically inspected in living individuals and is highly resistant to chemical and physical interferences, in addition to being considered the best record for evolutionary changes (Kaushal et al., 2003). Dental pulp, dentin, and cementum show changes related to the age, pathological changes, and physiological factors of individuals. The fully formed enamel does not show agerelated changes, except for the loss of permeability and increased fragility (Morse, 1991; Yang et al., 2006). Thus, due to its highly mineralized composition, the tooth has extensive longevity and represents an important element of human aging, with the ability to help to estimate the age of individuals (Kanchan-Talreja et al., 2012).

Dental age can be determined from three characteristics: tooth eruption, amount of root resorption of primary teeth, and amount of development of permanent teeth (Lopez et al., 2013).

The methods involving the identification of the mineralization stages of teeth are simple, performed from the analysis of radiographic images in which dental images are compared with the standard stage to estimate the age range of individuals (Liversidge et al., 2003; Chaillet et al., 2004; Luca et al., 2010).

Population samples for developing these methods represent one of the bases for estimating dental age, originating from specific populations in each country, such as Belgian children sampled using the Willems method (Willems et al., 2001) and Italian children with the Cameriere method (Cameriere et al., 2006).

The increased reliability of methods occurs when an age estimation technique is applied to different population groups (Šešelj et al., 2019). Cunha et al. (2009) highlight that the best methodologies are not those with the best standard deviation, but those that have been validated in different populations and are suitable for a given forensic scenario, in addition to being practical, easy to apply, and low-cost. Ubelaker \& Parra (2008) and Santoro et al. (2009) claim that high accuracy of age estimation occurs when using methods and equations specific to a particular population.

Sisman et al. (2007) developed a study that evaluated the estimate of chronological age based on the stages of third molar development according to the Demirjian method. They concluded that the use of third molars as a developmental marker is appropriate, especially when compared to the standard deviation obtained with other age estimation techniques, such as skeletal age calculation. In turn, Cameriere et al. (2008) compared the methods of Cameriere, Demirjian, and Willems to determine the accuracy of the Cameriere method in assessing the chronological age of children of both sexes through the relationship between the measurement of age and the open apex of teeth. The authors concluded that the Willems method is better than the Demirjian method but significantly less accurate than the Cameriere method.

Age estimation is crucial in countries that receive immigrants because many individuals enter the countries without documents. The study by Martin et al. (2008) aimed to analyze three different populations that immigrated to Spain to determine the pattern of development of third molars to serve as a tool for estimating the age of people with different ancestry and 
geographic origin. The authors concluded that socio-geographic factors are more significant than ancestry in third molar development. They also concluded that the Demirjian method was a good indicator of age for the three populations. Likewise, to analyze the average age of the mineralization stages relative to ethnic origin, Liversidge (2009) compared the stages of dental formation of individuals aged between 2 and 22 years, of both sexes, white and of Bangladeshi origin, using the Moorrees method. There were no significant differences regarding the mineralization stages and ethnicities, but they were observed between men and women for the stages of root mineralization of canines and apex of third molars. The average age of most dental mineralization stages found in this study was considered later than those proposed by Moorrees. The accuracy of age estimation in a separate sample of radiographs was considerably more accurate with these new data.

The study by Zeng et al. (2010) analyzed the mineralization stages of upper and lower third molars of 3,100 Chinese individuals, both women and men, aged between 4.1 and 26.9 years. The authors found that the mean chronological age and time to complete mineralization occurred earlier in men.

Fins et al. (2017) analyzed 367 panoramic radiographs of a group from the Portuguese population aged between 3 and 19 years to evaluate the mineralization stages of permanent lower second molars, as proposed by Demirjian. The authors did not find statistically significant differences between actual age and estimated age. Pereira et al. (2021) also used a Portuguese sample, analyzing lower third molars in 348 panoramic radiographs of individuals aged between 12 and 23 years. The correlation between age and third molars was 0.862 in the Cameriere method, while in the Demirjian method and Nolla and Moorrees phases methods, the correlation coefficients were 0.863, 0.842, and 0.844, respectively. The Demirjian method and the Cameriere method achieved similar results. At certain ages, the Nolla and Moorrees methods were more sensitive than the Cameriere method.

Widek et al. (2019) conducted the study with magnetic resonance images of 316 Austrian subjects aged between 13 and 25 years old, evaluating the mineralization stages and chronology of eruption of upper and lower third molars, according to the methods proposed by Demirjian and Olze. The $\mathrm{H}$ stage of mineralization in the sample studied represented a good factor for determining whether a person is older or younger than 18 years (99\% probability). Regarding the assessment of eruption, the final stage D was not such a clear indicator of adulthood (93\% probability).

Bedek et al. (2020) evaluated 1,868 panoramic radiographs of Croatian children aged 5 to 16 years to analyze the stages of tooth development. The analysis of this study was performed in combination with the Willems method. Among the results, the Willems method was considered adequate to estimate age among Croatian children.

Studies with Brazilian participants were also performed and resulted in important data. In 1974, Nicodemo, Moraes, \& Médici (NMM) realized the need to assess dental age from a table with Brazilian standards, because the foreign tables described in the literature were not compatible with the population of Brazil. The NMM table was developed using national data to estimate the age of individuals based on dental development. The authors were based on the mineralization stages of Nolla, transforming the 10 stages into just eight, and developed a table that associates the values discussed by Nolla with the maximum and minimum age in months for characterizing the dental stage (Nicodemo et al., 1974).

Franco et al. (2013) verified the Willems model in a Brazilian sample of 1,357 panoramic radiographs of individuals aged between 5 and 24 years. The accuracy of age estimation between the Willems model and the new Brazilian model was compared, concluding that the new Brazilian model developed provided age estimation performances similar to those of the Willems method. In contrast, Moreno et al. (2014) verified the assertiveness index for the chronological age of a sample of 94 panoramic radiograph images of individuals between 10 and 25 years old, using the mineralization table described in the study by Nolla according to the mineralization chronology of permanent teeth in Brazil created by Nicodemo, Moraes, and Medici. In this age group, the percentage of correct answers was higher only when four teeth were analyzed by panoramic radiography (81.9\%) compared to the analysis of 16 teeth (4.3\%). The analysis based on the image of third molars showed the highest percentage of correct answers (66\%) relative to the evaluation of the other teeth. There was no statistical difference between the 
percentage of correct answers when comparing the results for men and women in the total group ( $\mathrm{p}=0.479)$. The percentage of correct answers was higher when using the image of the sample between 10 and 15 years old (94.4\%) compared to those over 15 years old $(65 \%)$, with a statistically significant difference $(\mathrm{p}>0.001)$. The results were more satisfactory when evaluating only four teeth, mainly in the age group from 10 to 15 years old.

The study by Azevedo et al. (2015) used the method of Cameriere et al. (2004) to develop a specific formula to estimate the age of the Brazilian adult population and compare it with the Cameriere formula. The results showed that the Brazilian formula developed from the group studied was more accurate than the Cameriere formula. However, the authors stressed that other factors still need to be considered to improve age estimation in adults. Deitos et al. (2015) also evaluated the Cameriere method to discriminate whether an individual is younger or older than 18 years from the third molar maturity index. A total of 444 panoramic radiographs were analyzed and the method showed $87 \%$ correct classification.

Veras et al. (2021) evaluated the reliability of the method proposed by Cornélio Neto (2000) to estimate the chronological age by analyzing the mineralization of third molars. The author used 150 panoramic radiographs of Brazilian individuals of both sexes aged between 15 and 22 years. The mineralization stages of the third molars (teeth 18, 28, 38, and 48) of the participants were recorded, according to the Brazilian table by Nicodemo et al. (1974) and adapted by Cornélio Neto (2000). The authors used an agreement classification that established the following levels: null, mediocre, moderate, good, and excellent. Most of the results observed a moderate agreement and only tooth 18, in men, showed good agreement. The authors concluded that this method can be used as an additional test to estimate the actual age of individuals.

However, some of the methods mentioned have not been tested in Brazilian individuals, such as the Olze method. This method, which assesses the radiographic visibility of the pulp of lower third molars, has shown good results in other populations (Guo et al., 2018). In a similar situation is the Moorrees method. Additionally, experiments with the NMM table (from 1974) did not obtain effective results (Moreno et al., 2014; Veras et al., 2021). Data referring to mineralization stages used in the NMM method were acquired in the late 1960s and early 1970s - more than half a century ago-, and may no longer be consistent with the current reality. There are no up-to-date data in the literature referring to the mineralization stages of permanent teeth of the Brazilian population. Thus, studies performed with this population are required, considering it is not recommended to use data obtained from one population and apply them to another. Ubelaker \& Parra (2008) and Santoro et al. (2009) reinforce that high accuracy of age estimation occurs when using the equations for a specific population, allowing an increase in method reliability.

\section{Final Considerations}

Age estimation is required in many situations, for both the living and the dead. The scientific literature presents different methods to estimate the age of individuals, highlighting dental analysis. This is especially important in estimating the age of young individuals. Teeth are resistant to environmental factors and their development is rarely affected by exogenous or endogenous factors.

The analysis of the dental mineralization stages performed with data from a specific population has contributed substantially. According to the survey in this study, the Willems and Demirjian methods were efficient in foreign populations, and the Moorrees method showed a higher sensitivity for estimating age in younger populations. Thus, it is worth noting the need for current studies with the Brazilian population, as the application of data obtained from a foreign population is not indicated for estimating age in another population.

Moreover, some of the methods used to estimate age through dental mineralization have not been tested in Brazilian individuals, and existing data relating to stages of dental mineralization date back to the 1960s and 1970s, requiring current and specific data from the Brazilian population. The results of new studies could benefit society, helping the clarification of Justice in real-life situations. 


\section{Acknowledgments}

\section{Funding}

This study was financed in part by the Coordenação de Aperfeiçoamento de Pessoal de Nível Superior - Brasil (CAPES) - Finance Code 001.

\section{References}

Azevedo, A. C., Alves, N. Z., Michel-Crosato, E., Rocha, M., Cameriere, R. \& Biazevic, M. G. (2015). Estimativa da idade dentária em uma população brasileira adulta pelo método de Cameriere. Braz Oral Res, 29, 1807-3107.

Babshet, M., Acharya, A. B. \& Naikmasur, V. G. (2011). Age estimation from pulp/tooth area ratio (PTR) in an Indian sample: A preliminary comparison of three mandibular teeth used alone and in combination. J Forensic Leg Med, 18(8)350-4.

Bedek, I., Dumančić, J., Lauc, T., Marušić, M. \& Čuković-Bagić, I (2020). New model for dental age estimation: Willems method applied on fewer than seven mandibular teeth. Int J Legal Med, 134(2), 35-743.

Brasil. (1940). Decreto Lei $n^{o} 2.848$ de 07 de Dezembro de 1940. Código Penal Brasileiro. http://www.planalto.gov.br/ccivil_03/decretolei/del2848compilado.htm.

Brasil. (1988). Constituição Federal de 1988. http://www.planalto.gov.br/ccivil_03/constituicao/ConstituicaoCompilado.htm

Brasil. (1990a). Decreto $n^{o} 99.710$ de 21 de novembro de 1990. http://www.planalto.gov.br/ccivil_03/decreto/1990-1994/d99710.htm

Brasil. (1990b). Lei $n^{\circ} 8.069$ de 13 de Julho de 1990. Estatuto da Criança e do Adolescente. http://www.planalto.gov.br/ccivil_03/leis/L8069Compilado.htm

Cameriere, R., Ferrante, L. \& Cingolani, M. (2004). Variations in pulp/tooth area ratio as an indicator of age: A preliminary study. J Forensic Sci, 49(2), 317319.

Cameriere, R., Ferrante, L. \& Cingolani, M. (2006). Age estimation in children by measurement of open apices in teeth. Int J Legal Med, 120(1), 49-52.

Cameriere, R., Ferrante, L., Angelis, D., Scarpino, F. \& Galli F. (2008). The comparison between measurement of open apices of third molars and Demirjian stages to test chronological age of over 18-year olds in living subjects. Int. J. Legal Med, 122, 493-497.

Cameriere, R., Ferrante, L., Belcastro, M. G., Bonfiglioli, B., Rastelli, E. \& Cigolani, M. (2007). Age estimation by pulp/tooth ratio in canines by mesial and vestibular peri- apical X-rays. J Forensic Sci, 52(5), 1151-1155.

Carvalho, A. A., Carvalho, A. \& Santos Pinto, M. C. (1990). Estudio radiográfico do desenvolvimento da dentição permanente de crianças brasileiras com idade cronológica variando entre 84 e 131 meses. Rev Odontol UNESP, 19 (1) 31-39.

Chaillet, N., Willems, G.\& Demirjian, A. (2004). Dental maturity in Belgian children using Demirjian's method and polynomial functions: new standard curves for forensic and clinical use. J Forensic Odontostomatol, 22(2), 18-27.

Cornélio Neto, L.W (2000). Estimativa da idade pela mineralização dentária dos $3^{\circ}$ molares através de radiografias panorâmicas. Dissertação. Universidade Estadual de Campinas, São Paulo, Brasil.

Cunha, E., Baccino, E., Martrille, L., Ramsthaler, F., Prieto, J., Schuliar, Y., Lynnerup, N. \& Cattaneo, C. (2009). The problem of aging human remains and living individuals: a review. Forensic Sci Int, 193(1-3),1-13.

Deitos, A. R., Costa, C., Michel-Crosato, E., Galić, I., Cameriere, R. \& Biazevic, M. G. (2015). Age estimation among Brazilians: Younger or older than 18? J Forensic Leg Med, 33(1)111-5.

Demirjian, A., Goldstein, H. (1973). New systems for dental maturity based on seven and four teeth. Ann Hum Biol. 3(5)411-21.

Demirjian, A., Goldstein, H. \& Tanner, J. M. (1973). A new system of dental age assessment. Hum Biol, 45(2), $211-27$.

Engström, C., Engström, H. \& Sagne, S. (1983). Lower third molar development in relation to skeletal maturity and chronological age. Angle Orthod, 53(2), 97106.

Figueira Júnior, E. \& Moura, L. C. L. (2014). A importância dos arcos dentários na identificação humana. Rev. bras. Odontol, 71(1), $22-7$.

Fins, P., Pereira, M. L., Afonso, A., Pérez-Mongiovi, D. \& Caldas, I. M. (2017). Chronology of mineralization of the permanent mandibular second molar teeth and forensic age estimation. Forensic Sci Med Pathol, 13(3), 272-277.

Franco, A., Thevissen, P., Fieuws, S., Souza, P. H. \& Willems, G. (2013). Applicability of Willems model for dental age estimations in Brazilian children. Forensic Sci Int. 10(231), 1-3.

Garamendi, P. M., Landa, M. I., Ballesteros, J. \& Solano, M. A. (2005). Reliability of the methods applied to assess age minority in living subjects around 18 years old. A survey on a Moroccan origin population. Forensic Sci Int, 154(1),3-12.

Guo, Y.C., Chu. G., Olze, A., Schmidt, S., Schulz, R., Ottow, Pfeiffer H, Chen T, Schmeling C. \& Schmeling, A. (2018). Application of age assessment based on the radiographic visibility of the root pulp of lower third molars in a northern Chinese population. Int J Legal Med, 132(3)825-829. 
Harris, E.F. (2007). Mineralization of the mandibular third molar: a study of American blacks and whites. Am J Phys Anthropol, 132(1), 98-109.

Kanchan-Talreja, P., Acharya, A.B. \& Naikmasur, V.G. (2012). An assessment of the versatility of Kvaal's method of adult dental age estimation in Indians. Arch Oral Biol, 57(3)277-84.

Kaushal, S., Patnaik, V. V. G. \& Agnihotri, G. (2003). Mandibular Canines In Sex Determination. J Anat. Soc, 52(2),119-124.

Kim, Y. K., Kho, H. S. \& Lee, K. H. (2000). Age estimation by occlusal tooth wear. J Forensic Sci, 45(2)303-9.

Koshy, S. \& Tandon, S. (1998). Dental age assessment: the applicability of Demirjian's method in south Indian children. Forensic Sci Int. 8(1-2), 73-85.

Kvaal, S. I. (2006). Collection of post mortem data: DVI protocols and quality assurance. Forensic Sci Int, 15(159)12-4.

Liversidge, H. M. (2009). Permanent tooth formation as a method of estimating age. Front Oral Biol. 13,153-157.

Liversidge, H. M., Lyons, F. \& Hector, M. P. (2003). The accuracy of three methods of age estimation using radiographic measurements of developing teeth. Forensic Sci Int, 131(1), 22-9.

Lopez, T. T., Arruda, C. P., Rocha, M., Rosin, A. S., Michel-Crosato, E. \& Biazevic, M. G. (2013). Estimating ages by third molars: stages of development in Brazilian young adults. J Forensic Leg Med, 20(5), 412-8.

Luca, S., Alemán, I., Bertoldi, F., Ferrante, L., Mastrangelo, P., Cingolani, M, \& Cameriere, R. (2010). Age estimation by tooth/pulp ratio in canines by periapical X-rays: reliability in age determination of Spanish and Italian medieval skeletal remains. J. Arch Sci, 32(12), 3058.

Martin-de las Heras, S., García-Fortea, P., Ortega, A., Zodocovich, S. \& Valenzuela, A. (2008). Third molar development according to chronological age in populations from Spanish and Magrebian origin. Forensic Sci Int, 15 (1),47-53.

Meinl, A., Huber, C. D., Tangl, S., Gruber, G. M., Teschler-Nicola, M. \& Watzek, G. (2008). Comparison of the validity of three dental methods for the estimation of age at death. Forensic Sci Int, 4(2-3)96-105.

Melo, K., Gimenez, C., Gomes, V., Bertoz, A., Bertoz, F. \& Moreira, A. (2020). Revisão sistemática dos métodos de correlação entre a idade dentária e cronológica em função das análises de Demirjian. Rev Bras Criminal, 9(2), 123-133.

Mincer, H. H., Harris, E. F. \& Berryman, H. E. (1993). The ABFO study of third molar development and its use as an estimator of chronological age. J Forensic Sci, 38(2), 379-390.

Miranda, S. S., Neves, D. M. P., Gomes, F. J. S. \& Corte-Real, A. T. (2015). A Estimativa da idade pela mineralização dentária utilizando o método de Nicodemo, Morais e Médici Filho (1974). em população portuguesa. Arq. Odontol, 51(3), 158-164.

Mohd Yusof, M. Y. P., Wan Mokhtar, I., Rajasekharan, S., Overholser. R. \& Martens, L. (2017). Performance of Willem's dental age estimation method in children: A systematic review and meta-analysis. Forensic Sci Int, 280(245), 1-245.

Moorrees, C. F. A., Fanning, E. A. \& Hunt Jr, E. E. (1963). Formation and resorption of three deciduous teeth in children. Am J Phys Anthropol, $21,205-213$.

Moreno, M. B. P., Pontes, T. J. P. \& Rabello, P. M. (2014). Utilização da Tabela de cronologia de mineralização dental de Nicodemo, Moraes e Médici Filho na estimativa da idade de paraibanos. Saúde, Ética e Justiça, 19(1),35-44.

Morse, D. R. (1991). Age-related changes of the dental pulp complex and their relationship to systemic aging. Oral Surg Oral Med Oral Pathol, 72(6), 721-45.

Nicodemo, R. A., Moraes, L. C. \& Médici Filho, E. (1974). Tabela cronológicada mineralização dos dentes permanentes entre brasileiros. Rev Fac Odontol, 3(1), 55-6.

Olze, A., Solheim, T., Schulz, R., Kupfer, M. \& Schmeling, A. (2010). Evaluation of the radiographic visibility of the root pulp in the lower third molars for the purpose of forensic age estimation in living individuals. Int J Legal Med, 124(3), 183-6.

Pereira, C. P., Rodrigues, A., Santos, A., Salvado, F., Santos, R. \& Cameriere, R. (2021). Cut-off for the legal ages in the Portuguese Population by Third Maturity Index: Measures of Accuracy. Arch Oral Biol, 125, 105089.

Pereira, A. S., Shitsuka, D. M., Parreira, F. J., \& Shitsuka, R. (2018). Metodologia da Pesquisa Científica. Retrieved from https://repositorio.ufsm.br/bitstream/handle/1/15824/Lic_Computacao_Metodologia-Pesquisa-Cientifica.pdf?sequence=1.

Santoro, V., Donno, A., Marrone, M., Campobasso, CP. \& Introna, F. (2009). Forensic age estimation of living individuals: a retrospective analysis. Forensic Sci Int, 193(1-3), 129.e1-4.

Schmeling, A., Geserick, G., Reisinger, W. \& Olze, A. (2007). Age estimation. Forensic Sci Int, 17(165), 2-3.

Šešelj, M., Sherwood, R. J. \& Konigsberg, L. W. (2019). Timing of Development of the Permanent Mandibular Dentition: New Reference Values from the Fels Longitudinal Study. Anat Rec (Hoboken), 302(10), 1733-1753.

Sisman, Y., Uysal, T., Yagmur, F. \& Ramoglu, S. I. (2007). Third-molar development in relation to chronologic age in Turkish children and young adults. Angle Orthod, 77(6), 1040-5.

Ubelaker, D. H. \& Parra, R. C. (2008). Application of three dental methods of adult age estimation from intact single rooted teeth to a Peruvian sample. $J$ Forensic Sci, 53(3)608-11.

Veras, N. P., Abreu-Pereira, C. A., Kitagawa, P. L. V., Costa, M. A., Lima, L. N. C., Costa J. F. \& Casanovas, R. C. (2021). Evaluation of an age estimate method by dental mineralization of third molars. Researc. Soc. Develp, 10(7), e19410716524. 
Research, Society and Development, v. 10, n. 11, e598101119481, 2021

(CC BY 4.0) | ISSN 2525-3409 | DOI: http://dx.doi.org/10.33448/rsd-v10i11.19481

Widek, T., Genet, P., Merkens, H., Boldt, J., Petrovic, A., Vallis, J.\& Scheurer, E. (2019). Dental age estimation: The chronology of mineralization and eruption of male third molars with 3 TMRI. Forensic Sci Int, 297, 228-235.

Willems, G., Van Olmen, A., Spiessens, B.\& Carels, C. (2001). Dental age estimation in Belgian children: Demirjian's technique revisited. J Forensic Sci, 46(4), 893-5.

Yang, F., Jacobs, R.\& Willems, G. (2006). Dental age estimation through volume matching of teeth imaged by cone-beam CT. Forensic Sci Int, 15 (1), $78-83$.

Yassin, S. M. M., AlAlmai, B. A., Ali Huaylah, S. H., Althobati, M. K. A., AlHamdi, F. M. \& Togoo, R. A. (2020). Accuracy of Estimating Chronological Age from Nolla's Method of Dental Age Estimation in a Population of Southern Saudi Arabian Children. Niger J Clin Pract, 23(12), 1753-1758.

Zeng, D. L., Wu, Z. L. \& Cui, M. Y. (2010). Chronological age estimation of third molar mineralization of Han in southern China. Int J Legal Med. 124(2), 11923. 